\title{
Effects of Dietary Fiber on Growth Performance, Fat Deposition, Fat Metabolism, and Expression of Lipoprotein Lipase Mrna in Two Breeds of Geese
}

\section{-Author(s)}

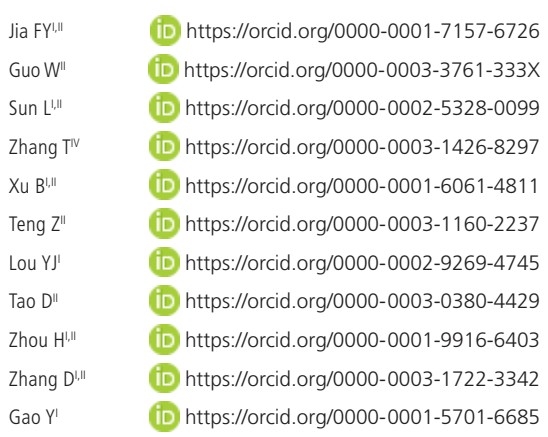

Key laboratory of Straw Biology and Utilization, The Ministry of Education, Chang Chun City, Jlin Prov. China 130118.

" College of Animal Science and Technology, Jilin Agricultural University, Chang Chun City, Jlin Prov. China 130118

III Jilin Province Animal Husbandry General Station, Chun City, Jlin Prov. China 130062

iv Jilin Province Science and Technology Innovation Platform Management Center, Chun City, Jlin Prov. China 130012

\section{-Mail Address}

Corresponding author e-mail address Haizhu Zhou

College of Animal Science and Technology, Jilin Agricultural University, Changchun City, Jilin Province, China 130118.

Phone: 043118946513177

Email: zhou haizhu@jlau.edu.cn

\section{- Keywords}

Body Fat; Dietary Fiber; LPL Expression; Serum Lipid.

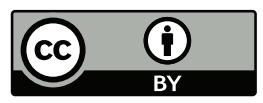

Submitted: 14/December/2020 Approved: 03/May/2021

\section{ABSTRACT}

The present study was conducted to investigate the effects of dietary fiber on growth performance, fat deposition, serum lipids, fat metabolism, and mRNA (messenger RNA) expression of lipoprotein lipase ( $L P L)$ in Jilin white and Carlos geese. Sixty Jilin white and sixty Carlos geese aged six-weeks and of similar health and weight (average weight $313.11 \mathrm{~g}$ ) were selected. Geese of each breed were randomly divided into two groups $(n=30)$, and with each group containing three replicate subgroups of 10 geese. The diet was supplemented with $8 \%$ or $11 \%$ fiber (corn straw powder). The Jilin white geese are divided into $A 1(8 \%)$ and $A 2(11 \%)$ groups, and Carlos geese are divided into B1 $(8 \%)$ and B2 (11\%) groups. The experiment lasted 35 days. The results showed that high dietary fiber can significantly $(p<0.05)$ increase average daily feed intake (ADFI), significantly $(p<0.05)$ reduce final weight (FW) and average daily gain (ADG) of both varieties, and increase LPL mRNA expression levels in abdominal fat, liver, sebum, and urethral glands. High dietary fiber accelerates intestinal peristalsis, affects the absorption of other nutrients, reduces the available energy value of the absorbed feed, and increases fat loss. Compared with the to Carlos geese, high dietary fiber content had a more significant effect on the live, slaughter, and sebum weights and sebum percentage of the Jilin white geese, indicating that the Carlos geese have higher requirements for dietary fiber content. High fiber content will reduce the growth performance, slaughter performance, and fat deposition of geese.

\section{INTRODUCTION}

Compared to other poultry, geese have minimal fiber requirements and can utilize the crude fiber of plant feed due to their specific digestive systems (Durant et al., 2003). During the process of raising geese, improving their dietary fiber level appropriately can reduce fat deposition and improve carcass quality while reducing feed cost and ensuring economic benefit (He et al., 2015). Few studies have investigated the effects of dietary fiber on the growth performance, digestive enzymes, and lipid metabolism of geese. Hsu et al. (1996) found that dietary lignin increased the feed intake of geese but decreased the feed conversion rate. He et al. (2015) reported that dietary fiber increased lipase and cellulase activity in the intestinal tract of geese. Jiang et al. (2012) reported that dietary alfalfa meals decreased abdominal fat percentages and concentrations of triglyceride (TG), total cholesterol (TC), and low-density lipoprotein cholesterol (LDLC). However, these results vary based on the growing environment and breed of geese and some conclusions deduced from the particular trial results may reflect bias, emphasizing the need for further research on the effects of dietary fiber on different breeds of geese. In the present study, Jilin white and Carlos geese were used to study the effects of different dietary fiber levels on 
Jia FY, Guo W, Sun L, Zhang T, Xu B, Teng Z, Lou YJ, Tao D, Zhou H, Zhang D, Gao Y

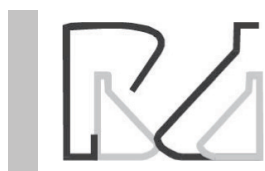

growth performance, body fat deposition, serum lipid concentration, and mRNA (messenger RNA) expression of lipoprotein lipase ( $L P L$ ). Additionally, we considered the molecular mechanisms by which dietary fiber levels affect lipid metabolism.

\section{MATERIALS AND METHODS}

\section{Experimental animals and design}

Using a $2 \times 2$ factorial design, a total of 120 6-weekold healthy adult male geese, of approximately equal weight, half of which were Jilin white geese and half of which were Carlos geese, were selected. The two breeds were divided into two groups $(n=30)$, respectively, and each group contains three replicates $(n=10)$. Corn straw (in powder form) was selected as the fiber source and the diet was supplemented with $8 \%$ or $11 \%$ fiber. Jilin white geese were divided into $A 1(8 \%)$ and $A 2(11 \%)$ groups, respectively, and Carlos geese were divided into $\mathrm{B} 1(8 \%)$ and B2(11\%) groups, respectively.

\section{Dietary composition and nutritional level}

The two experimental diets were formulated according to the NRC feeding standard of NRC (Pesti, 1995). Save for the percentages of crude fiber, the other nutrient levels were basically the same. The feed composition and calculated nutrient content are shown in Table 1.

Table 1 - Composition and nutritional ingredients of the diets (\%).

\begin{tabular}{lcc}
\hline Item & 8\% fiber level & 11\% fiber level \\
\hline Ingredients (\%) & & \\
\hline Corn & 53.90 & 51.10 \\
Soy meal & 21.00 & 13.00 \\
Corn stalk & 13.00 & 21.00 \\
\hline Zein & 10.00 & 13.00 \\
Stone powder & 1.30 & 1.10 \\
\hline Table salt & 0.30 & 0.3 \\
Additive & 0.5 & 0.5 \\
\hline Total & 100 & 100 \\
\hline Nutrition level & & \\
\hline Metabolic energy & 12.44 & 12.43 \\
Crude protein & 18.03 & 18.01 \\
Crude fiber & 8.01 & 11.02 \\
Calcium & 0.63 & 0.62 \\
Available phosphorus & 0.42 & 0.42 \\
Lysine & 0.97 & 0.98 \\
Methionine + Cystine & 0.61 & 0.62 \\
\hline
\end{tabular}

Note' Supplied per kilogram of premix: Vitamin A, 800000 IU; Vitamin D, 160000 IU, Vitamin E, 500 IU; Vitamin K, 50 mg; Zn (zinc oxide), 8000 mg; Mn (manganese sulfate), $6000 \mathrm{mg}$; Fe (ferrous sulfate), $6000 \mathrm{mg}$; Cu (copper sulfate), $800 \mathrm{mg}$; (calcium iodate), $35 \mathrm{mg}$; Se (sodium selenite), $30 \mathrm{mg}$; thiamin, $80 \mathrm{mg}$; riboflavin 250 mg; pantothenate, 220 mg; nicotinic acid, 2000 mg; pyridoxine, 300 mg; biotin, 10 $\mathrm{mg}$; folic acid, $25 \mathrm{mg}$. ${ }^{2}$ Values are calculated according to Tables of Feed Composition and Nutritive Values in China (2017).
Effects of Dietary Fiber on Growth Performance, Fat Deposition, Fat Metabolism, and Expression of Lipoprotein Lipase Mrna in Two Breeds of Geese

\section{Feed management}

The geese were provided with water ad libitum. Lighting was a combination of artificial and natural lighting, with a room temperature of $15 \pm 3{ }^{\circ} \mathrm{C}$ and relative humidity of $60 \%$. Fresh feed was provided three times a day, sink and feed troughs were cleaned twice a day, feces removed once a day, and the goose house was sterilized thoroughly at regular intervals to ensure a clean environment. The trial period lasted 35 days.

\section{Measurement indicators}

Growth performance: Five geese were randomly selected from each replicate and their bodyweight was measured weekly during the experiment. At the end of the experiment, the average daily gain (ADG) and average daily feed intake (ADFI) were recorded.

Fat metabolism rate: Excreta were collected using the total collection method (Matterson, 1965). On day 28 , one goose in each replicate with the average BW (body weight) of the replicate was selected. Each goose was placed in a separate metabolic cage $(75 \mathrm{~cm} \times 65 \mathrm{~cm} \times 35 \mathrm{~cm})$ with a pre-feeding period of 3 days and a formal testing period of 35 days. The geese entered the new environment on the 28th day and fasted for 12 hours from 19:00 7:00 p.m. on the 30th day to 7:00 a.m. on the 31st day. Feces were collected from $7 \mathrm{am}$ on the 31st day. The geese then fasted again for 12 hours from 19:00 7:00 p.m. on the 34th day to 7 am on the 35th day. Only water was provided for the geese during fasting. The collected feces were dried at $65{ }^{\circ} \mathrm{C}$, weighed, and sieved. The crude fat content of the excreta and diet samples was measured using the Soxhlet extraction method (Hawthorne et al., 2000). Calculation formula: metabolism $=$ (feed intake $\times$ nutrient diet - excreta output $\times$ nutrient excreta) / (feed intake $\times$ nutrient diet) $\times 100 \%$.

Fat deposition: At the end of the feeding experiment, geese with an average weight of 2 geese in each replicate were selected and made to fast for 12 hours. At slaughter, live weight, slaughter weight, semi-clean weight, visceral weight, chest muscle weight, leg muscle weight, and subcutaneous fat were recorded. Blood samples ( $5 \mathrm{ml}$ each) from all geese were collected from the wing veins at the same time, and the serum was separated by centrifugation (2000 rpm, 10 minutes). Analysis of high-density lipoprotein cholesterol (HDLC), LDLC, TC, triglycerides (TG), and glutamate-oxalyl (GOT) in the serum was conducted using an automated biochemical analyzer (AU640). A Chemical Immuno Analyzer manufactured by Japan 
Jia FY, Guo W, Sun L, Zhang T, Xu B, Teng Z, Lou YJ, Tao D, Zhou H, Zhang D, Gao Y

\section{Effects of Dietary Fiber on Growth Performance, Fat Deposition, Fat Metabolism, and Expression of Lipoprotein Lipase Mrna in Two Breeds of Geese}

Olympus was used. The abdominal fat rate was calculated as follows: abdominal fat rate $=$ (abdominal fat weight / eviscerated weight + abdominal fat weight) $\times 100 \%$; sebum rate $=$ (tare weight + subcutaneous fat weight + abdominal fat weight) / eviscerated weight $\times 100 \%$.

LPL gene expression volume: At the end of the experiment, the liver, abdominal fat, sebum samples, and uropygial gland samples from each goose were collected and stored at $-80^{\circ} \mathrm{C}$ until use. Total RNA was extracted using the Trizol two-step method (Meng et al., 2010) and integrity was detected by electrophoresis on a $0.7 \%$ agarose gel. Primer Premier 5.0and GenBank were used to co-design the gene sequences of $\beta$-actin and LPL to synthesize primers in Jinweizhi Biological Engineering Shengong Company (Table 2). LPL gene-specific primer sequences were used in the amplification process. A conventional PCR (Polymerase Chain Reaction) instrument (Thermo Fisher Scientific) was used for real-time PCR. An initial denaturation wasperformed on a thermal cycler at $94{ }^{\circ} \mathrm{C}$ for 5 minutes and then denatured at $95{ }^{\circ} \mathrm{C}$ for 40 cycles for 30 seconds each. Different annealing temperatures were specific to each primer. At the end of each PCR run, the dissociation curve of the amplified products was analyzed. For each treatment, three samples reacted and repeated twice. Detection of LPL gene mRNA expression was conducted using the double internal standard curve method of the TP800 thermal cycler dice real-time system (TaKaRa, Japan).

\section{Statistical analysis}

All data are presented as mean \pm standard deviation. Data were evaluated for statistical significance by

Table 2 - Primers of $\beta$-actin and LPL genes.

\begin{tabular}{lllll}
\hline Gene name & GenBank ID & Primer sequence 5'- 3' & Position & Fragment size (bp) \\
\hline LPL & NM 205282 & FP: GGACGGTGACAGGAATGTATGA & 312 \\
& RP: CAGCAGGATCCAGACCAGTAAT & $359-670$ & \\
$\beta$-actin & F26111.1 & FP: GACCACCTTCAACTCCATC & $903-1032$ & 130 \\
& & RP: GGCTGTGATCTCCTTCTG & 9 \\
\hline
\end{tabular}

Levene's test for equality of variances. $p<0.05$ was considered significant and $p<0.01$ was considered highly significant.

\section{RESULTS}

\section{Growth performance}

The effects of the dietary fiber on the growth performance of Jilin white and Carlos geese are listed in Table 3. At the beginning of the experiment, there was no significant difference in the initial weight of the geese, either between breeds or breed groups ( $p>0.05)$. After 35 days of the feed experiment, as the dietary fiber content increased the final weight (FW) and ADFI changed significantly. The FW of the geese in the low fiber group was significantly higher than that of the geese in the high fiber group $(p<0.05)$. The ADFI of the Jilin white and Carlos geese increased significantly with an increase in fiber level $(p<0.05)$. ADG decreased with an increase in dietary fiber. At the same dietary fiber level, the ADG of Carlos geese was significantly higher than that of Jilin white geese $(p<0.05)$.

Table 3 - Effects of dietary fiber on growth performance in different breeds of geese.

\begin{tabular}{|c|c|c|c|c|}
\hline Items & $\mathrm{A} 1(8 \%)$ & $\mathrm{A} 2(11 \%)$ & B1(8\%) & $\mathrm{B} 2(11 \%)$ \\
\hline IW (g) & $312.70 \pm 10.18$ & $312.70 \pm 10.18$ & $313.52 \pm 12.04$ & $313.52 \pm 12.04$ \\
\hline FW (g) & $379.10 \pm 15.18^{a}$ & $347.47 \pm 18.15^{b}$ & $451.52 \pm 17.04^{c}$ & $432.69 \pm 18.11^{d}$ \\
\hline ADFI (g) & $603.10 \pm 17.18^{a}$ & $706.47 \pm 19.15^{b}$ & $606.52 \pm 19.74^{c}$ & $693.69 \pm 18.11^{d}$ \\
\hline ADG $(g)$ & $39.00 \pm 3.22^{\mathrm{a}}$ & $27.82 \pm 4.34^{b}$ & $49.35 \pm 3.118^{c}$ & $38.18 \pm 5.24^{a}$ \\
\hline
\end{tabular}

Note: Different lowercase letters in the same column represent significant difference at 0.05 level; the same as below.IW, Initial weight; FW, final weight; ADFI, average daily feed intake; $A D G$, average daily gain.

\section{Fat metabolism}

The effects of dietary fiber on fat metabolism of the Jilin white and Carlos geese are listed in Table 4. With the increase in dietary fiber level, the food intake (FI) and fat metabolism rate (FMR) of Jilin white and Carlos geese decreased significantly $(p<0.05)$. The effect of dietary fat (FIF) on Jilin white geese was significant and dietary fat with high fiber content was low. There were no differences in other fat metabolism variables ( $p>0.05)$. At the same dietary fiber level, the effects of $\mathrm{FI}, \mathrm{FIF}$, EX (excretion), FE (fat excretion), and FMR in Jilin white geese were not significant. 
Table 4 - Effects of dietary fiber on fat metabolism in different breeds of geese.

\begin{tabular}{|c|c|c|c|c|}
\hline Items & $\mathrm{A} 1(8 \%)$ & $\mathrm{A} 2(11 \%)$ & B1(8\%) & B2(11\%) \\
\hline $\mathrm{FI}(\mathrm{g})$ & $454.53 \pm 11.34^{a}$ & $364.4 \pm 8.47^{b}$ & $470.53 \pm 9.93^{a}$ & $400.8 \pm 9.57^{\mathrm{ab}}$ \\
\hline EX (g) & $122.09 \pm 7.69$ & $106.74 \pm 5.59$ & $122 \pm 7.25$ & $123.2 \pm 8.12$ \\
\hline FIF (g) & $44.15 \pm 3.27^{a}$ & $34.01 \pm 2.84^{b}$ & $43.92 \pm 2.28^{a}$ & $38.93 \pm 2.03^{\mathrm{ab}}$ \\
\hline $\mathrm{FE}(\mathrm{g})$ & $14.12 \pm 0.27$ & $12.85 \pm 0.39$ & $13.06 \pm 0.98$ & $14.64 \pm 0.67$ \\
\hline FMR(\%) & $64.74 \pm 4.02^{\mathrm{a}}$ & $53.69 \pm 3.93^{b}$ & $66.12 \pm 5.36^{a}$ & $52.48 \pm 3.27^{b}$ \\
\hline
\end{tabular}

NOTE:FI, food intake; EX, excretion; FIF, dietary fat; FE, fat excretion; FMR, fat metabolism rate.

\section{Fat deposition}

The effects of dietary fiber on body fat deposition in the Jilin white and Carlos geese are listed in Table 5. With the increase of dietary fiber level, the live weight, slaughter weight, sebum weight, and abdominal fat weight of Jilin white geese decreased significantly $(p<0.05)$ and the difference between sebum percentage and abdominal fat percentage was not significant.
The abdominal fat weight of Carlos geese decreased significantly $(p<0.05)$ and live weight, slaughter weight, sebum weight, sebum percentage, and abdominal fat percentage decreased, but the effect was not significant ( $p>0.05)$. Compared at the same fiber level, the comparison between Carlos geese and Jilin white geese showed that abdominal fat rate, sebum, and sebum rate were significantly reduced $(p<0.05)$.

Table $\mathbf{5}$ - Effects of dietary fiber on body fat deposition in different breeds of geese.

\begin{tabular}{|c|c|c|c|c|}
\hline Items & $\mathrm{A} 1(8 \%)$ & $A 2(11 \%)$ & $\mathrm{B} 1(8 \%)$ & $\mathrm{B} 2(11 \%)$ \\
\hline Live weight $(\mathrm{kg})$ & $4.68 \pm 0.28^{b}$ & $3.75 \pm 0.67^{\mathrm{a}}$ & $4.16 \pm 0.72^{\mathrm{ab}}$ & $3.77 \pm 0.68^{a}$ \\
\hline Slaughter weight (kg) & $4.12 \pm 0.17^{b}$ & $3.28 \pm 0.66^{a}$ & $3.59 \pm 0.64^{\mathrm{ab}}$ & $3.29 \pm 0.58^{a}$ \\
\hline Sebum weight (g) & $488.11 \pm 12.43^{a}$ & $393.24 \pm 9.06^{b}$ & $345.88 \pm 9.69^{b}$ & $311.80 \pm 9.11^{b}$ \\
\hline Sebum rate (\%) & $19.43 \pm 1.3^{a}$ & $17.1 \pm 0.17^{\mathrm{ab}}$ & $14.08 \pm 0.9^{b}$ & $13.81 \pm 0.50^{\mathrm{b}}$ \\
\hline Abdominal fat weight (g) & $56.88 \pm 5.49^{a}$ & $38.76 \pm 3.54^{b}$ & $33.68 \pm 3.60^{b}$ & $28.66 \pm 2.89^{c}$ \\
\hline Abdominal fat rate (\%) & $1.94 \pm 0.23^{a}$ & $1.68 \pm 0.28^{\mathrm{ab}}$ & $1.36 \pm 0.30^{b}$ & $1.25 \pm 0.30^{b}$ \\
\hline
\end{tabular}

TC, LDLC, and GOT in the four groups of $A 1, A 2$, $B 1$, and B2 decreased with an increase in dietary fiber (Table 6) but the differences were not significant
( $p>0.05)$. When the dietary fiber content increased, triglycerides increased but the effect was not significant ( $p>0.05)$.

Table 6 - Effects of dietary fiber on blood lipids in different breeds of geese.

\begin{tabular}{|c|c|c|c|c|}
\hline Items & $\mathrm{A} 1(8 \%)$ & $\mathrm{A} 2(11 \%)$ & B1(8\%) & B2(11\%) \\
\hline $\mathrm{TG}(\mathrm{mmol} / \mathrm{L})$ & $1.07 \pm 0.45$ & $1.18 \pm 0.14$ & $1.17 \pm 0.10$ & $1.42 \pm 0.35$ \\
\hline $\mathrm{TC}(\mathrm{mmol} / \mathrm{L})$ & $4.20 \pm 0.48$ & $3.99 \pm 1.01$ & $4.59 \pm 0.34$ & $4.31 \pm 0.65$ \\
\hline $\mathrm{HDLC}(\mathrm{mmol} / \mathrm{L})$ & $2.60 \pm 0.15^{\mathrm{ab}}$ & $2.34 \pm 0.27^{a}$ & $2.89 \pm 0.35^{b}$ & $2.47 \pm 0.02^{\mathrm{ab}}$ \\
\hline LDLC (mmol/L) & $1.23 \pm 0.32$ & $1.33 \pm 0.47$ & $1.30 \pm 0.01$ & $1.41 \pm 0.12$ \\
\hline GOT (IU/L) & $28.20 \pm 1.00$ & $23.20 \pm 0.54$ & $18.50 \pm 0.89$ & $29.00 \pm 0.98$ \\
\hline
\end{tabular}

NOTE:TC, Total cholesterol; TG, Triglyceride; HDLC, High density lipoprotein; LDLC, low density lipoprotein; GOT, Aspartate aminotransferase;

\section{Relative expression of LPL MRNA}

Figure 1 shows the integrity of the RNA, with bright bands clearly visible. The results of the $L P L$ gene $P C R$ are shown on the left in Figure 2 and the results of $\beta$-actin PCR are shown on the right in Figure 2 .

The effects of dietary fiber on the relative expression of LPL mRNA in the tissues of Jilin white and Carlos geese are listed in Table 7. The expression levels of $L P L$ in different tissues were ranked as abdominal fat> sebum $>$ liver $>$ urethral gland. The relative expression levels of $L P L$ mRNA in abdominal fat, liver, sebum, and urethral glands of the Jilin white and Carlos geese significantly decreased with an increase in dietary fiber level $(p<0.05)$. At the same dietary fiber level, the relative expression levels of $L P L$ mRNA in abdominal fat, liver, sebum, and urethral glands of the Carlos geese were significantly higher than those of the Jilin white geese $(p<0.05)$.

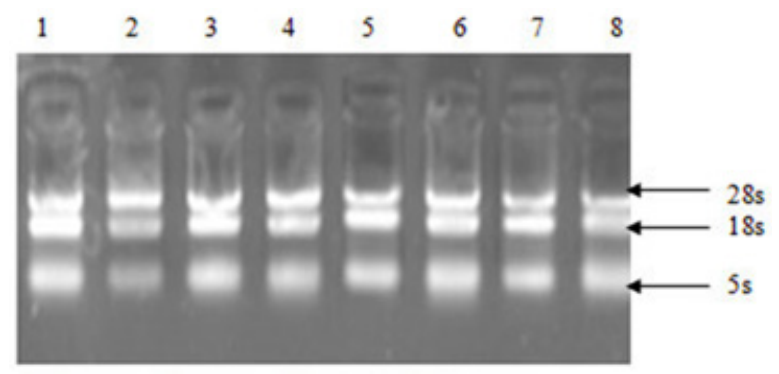

Figure 1 - The electrophoresis figure of total RNA extraction. Note: 1-2 liver, 3-4 abdominal fat, 5-6 sebum, 7-8 uropygial gland. 
Table 7 - Effects of dietary fiber on relative expression of $L P L$ mRNA in tissues of geese.

\begin{tabular}{|c|c|c|c|c|}
\hline Items & $\mathrm{A} 1(8 \%)$ & A2(11\%) & B1(8\%) & B2(11\%) \\
\hline Abdominal fat & $8.60 \pm 0.17^{a}$ & $6.75 \pm 0.11^{b}$ & $20.13 \pm 3.13^{c}$ & $9.41 \pm 0.45^{d}$ \\
\hline liver & $1.35 \pm 0.22^{\mathrm{a}}$ & $1.08 \pm 0.12^{b}$ & $3.66 \pm 0.77^{c}$ & $2.31 \pm 0.30^{d}$ \\
\hline Sebum & $2.56 \pm 0.03^{a}$ & $1.56 \pm 0.55^{b}$ & $6.08 \pm 0.19 c$ & $3.30 \pm 0.76^{d}$ \\
\hline Uropygial gland & $0.10 \pm 0.01^{a}$ & $0.06 \pm 0.02^{b}$ & $0.14 \pm 0.03^{c}$ & $0.10 \pm 0.04^{a}$ \\
\hline
\end{tabular}

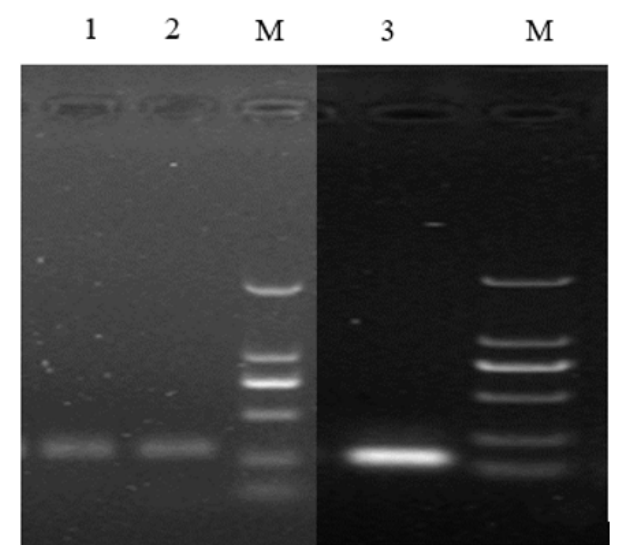

Figure $\mathbf{2}$ - The PCR amplification results

1 and 2, the amplified fragment of LPL gene;3, the amplified fragment of $\beta$-actinfragment

Table 8 shows the correlation analysis between the relative expression of specific parts of the geese's $L P L$ mRNA and some fat traits. The abdominal fat weight and the triglyceride $L P L$ mRNA content in the Jilin white geese showed a significant correlation and sebum weight was significantly positively correlated with the LPL mRNA of sebum. The abdominal fat weight of the Carlos geese was significantly correlated with the content of $L P L$ mRNA in abdominal fat. Liver and triglyceride $L P L$ mRNA showed a significant correlation with a significant coefficient.

\section{DISCUSSION}

Dietary fiber is an important energy resource for poultry and dietary supplementation. An appropriate amount of fiber could promote the growth and development of geese (Yu et al., 1998). Hsu et al. (2000b) reported that feed intake was significantly higher in the group with high crude fiber (CF). Jin et al. (2014) reported that 4\% CF increased the ADFI by more than 2\%. However, previous studies showed that high CF levels also decreased the ADG of poultry. Broilers fed a diet with $4.7 \%$ CF had decreased ADG compared with treatment with $4.0 \%$ CF (Tabook et al., 2006). Six percent CF has a negative effect on ADG compared to 4\% CF in goslings (Jing et al., 2016). Our results revealed that $11 \% \mathrm{CF}$ improved $A D F I$ more than $8 \%$ CF but decreased ADG during the 35th day feeding experiment, a result consistent with previous reports. High fiber content increases intestinal peristalsis and promotes an increase in the feed intake of geese but it affects the absorption of other nutrients, reduces the available energy value of the feed, and increases the loss of protein and fat. The FW and ADG were significantly higher in Carlos geese than in Jilin white geese, perhaps due to the differences between the breeds' digestive capacities for CF.

The increase in the number of fat cells in the early stage of poultry affects the progressive formation of fat deposits in the later stage (Hansen et al., 2013). The fat deposits are affected by genetic factors (Ye et al., 2014), nutritional levels (Senousey et al., 2014), and other factors. Dietary fiber is one of the most important factors affecting fat deposition. Mateos (2012) found that a high dietary fiber level could reduce fat synthesis function. Shotorkhoft et al. (2012) reported that the dietary supplement of grass meal can reduce body fat deposition in geese. In the present study, the abdominal fat weight and sebum weight of geese at the $8 \%$ dietary fiber level were significantly lower $(p<0.05)$ than those at the $11 \%$ fiber level. These results are consistent with previous studies. In general, crude fibers affect fat metabolism in three respects: first, crude fibers accelerate the speed at which chyme

Table 8 - Correlations between the LPL mRNA expressions related to adipose in geese.

\begin{tabular}{|c|c|c|c|c|c|c|c|c|}
\hline Item & Breed & Abdominal fat & Sebum & TG & TC & $\mathrm{HDL}$ & LDL & GOT \\
\hline \multirow[t]{2}{*}{ Abdominal fat } & Jilin White & 0.701 & 0.803 & $0.871 *$ & -0.158 & 0.579 & -0.389 & -0.55 \\
\hline & Carlos & $0.855^{*}$ & 0.368 & 0.506 & 0.57 & 0.747 & 0.624 & -0.046 \\
\hline \multirow[t]{2}{*}{ liver } & Jilin White & 0.797 & 0.799 & 0.140 & -0.165 & 0.639 & -0.402 & -0.532 \\
\hline & Carlos & 0.168 & 0.369 & $0.874^{*}$ & 0.525 & 0.717 & 0.603 & 0.002 \\
\hline \multirow[t]{2}{*}{ Sebum } & Jilin White & 0.798 & $0.862 *$ & 0.279 & 0.13 & 0.572 & -0.383 & -0.618 \\
\hline & Carlos & 0.120 & 0.366 & 0.509 & 0.632 & -0.784 & 0.596 & -0.118 \\
\hline
\end{tabular}

Note: * Significant correlation at 0.05 level (both sides) 
Jia FY, Guo W, Sun L, Zhang T, Xu B, Teng Z, Lou YJ, Tao D, Zhou H, Zhang D, Gao Y
Effects of Dietary Fiber on Growth Performance, Fat Deposition, Fat Metabolism, and Expression of Lipoprotein Lipase Mrna in Two Breeds of Geese passes through the intestinal tract, reducing the chance for fat to be absorbed by intestinal cells (Yost et al., 1998). Second, crude fibers limit lipid intake and accelerate bile acid removal by combining with bile acid in the digestive tract (Vicente et al.,2013). Third, crude fiber can reduce cholesterol and fat synthesis by reducing dietary energy absorption in poultry (Hermier et al., 1997).

If endogenous and exogenous fat metabolites transit to tissues and organs, it must be through blood circulation (Davidson, 2015). Therefore, the level of serum lipids reflects the overall body fat metabolism. The main serum lipids are TG, TC, HDLC, LDLC, and GOT (Bredella et al., 2013). The TG content of blood plasma can reflect the degree of fat deposition in the adipose tissue of poultry (Senousey et al., 2014) and LDLC and HDLC are the main particles that transport cholesterol (Petzinger et al., 2013). Jin et al. (2014) reported that high dietary fiber decreased the serum TG of goslings. Pectin and lignin in dietary fiber can be combined with cholesterol and bile acids, respectively, and then be excreted, thereby reducing the accumulation of cholesterol, lowering TG and cholesterol in the serum and liver, and lowering blood lipids (Jenkins et al., 2002). Roberts et al. (2002) found that a high-fiber diet can reduce the TC content and thus reduce the risk of cardiovascular disease. In the present study, with an increase in dietary fiber level, the concentrations of TG, TC, and LDLC, and the activity of GOT all showed decreasing trends, consistent with previous studies. The test data show that TC, LDLC, GOT may not be obvious because of the short feeding time.

The $L P L$ gene is a key enzyme for fat deposition. Liang \& Vaziri (1997) found that the mRNA expression of the $L P L$ gene affects fat deposition in the viscera and that the activity and expression of LPL mRNA was induced by the liver. Roberts et al. (2002) found that the activity and expression of LPL mRNA significantly increased in rats fed a high-carbohydrate diet. $L P L$ gene expression increases fat deposition. In the present study, the results showed that the expression of LPL mRNA in abdominal fat, liver, sebum, and the uropygial gland was significantly decreased at the $11 \%$ dietary fiber level $(p<0.05)$. There was a significant positive correlation between the abdominal weight of Carlos geese and the relative expression of LPL mRNA in abdominal fat $(p<0.05)$, and a positive correlation between the expression of $L P L$ mRNA in the liver and triglycerides $(p<0.05)$. The expression of LPL mRNA in the abdominal fat of Jilin white geese was significantly positively correlated with TG $(p<0.05)$ and the expression of LPL mRNA in fat was significantly positively correlated with sebum weight $(p<0.05)$. This conclusion is similar to that of Roberts et al. (2002). The expression of LPL mRNA in abdominal fat, liver, sebum, and the uropygial gland was higher in Carlos geese than in Jilin white geese at the same fiber level, which is consistent with the results of Roberts' research. Yang et al. (2009) found that the expression volumes of the $L P L$ gene were significantly different in different fat tissues and that the order of expression volumes was muscle > abdominal fat > liver. In this experiment, the order of expression volumes was abdominal fat $>$ sebum $>$ liver $>$ uropygial gland, similar to the study by Yang et al.(2009).

\section{CONCLUSION}

Our results showed that high dietary fiber could reduce abdominal fat, liver weight, sebum, urethral glands, body lipids, serum lipid deposition, and LPL mRNA expression levels of geese. Furthermore, the capacity for digestion of dietary fiber in Carlos geese is higher than that of Jilin white geese. These results provide a useful reference for the application of dietary fiber in the production of geese.

\section{ACKNOWLEDGMENTS}

The work was supported by Jilin Province (China) Science and Technology Development Plane (20200201173JC). We would like to thank Editage (www.editage.cn) for English language editing.

\section{CONFLICT OF INTEREST STATEMENT}

We declare that there are no commercial or association conflicts of interest with the work submitted, and this manuscript was not submitted elsewhere. All authors agree to send the article to Brazilian Journal of Poultry Science.

\section{REFERENCES}

Azizi-Shotorkhoft A, Rouzbehan Y, Fazaeli H. The influence of the different carbohydrate sourceson utilization efficiency of processed broiler litter in sheep. Livestock Science 2012;148:249-254.

Bredella MA, Gill CM, Gerweck AV, Landa MG, Kumar V, Daley SM, et al. Ectopic andserum lipid levels are positively associated with bone marrow fat in obesity. Radiology 2013;269:534-541.

Daphné D, Hervé F, Blais S, et al. The functional response in three species of herbivorousAnatidae:Effects of sward height, body mass and bill size. Journal of Animal Ecology 2003;72:220-231.

Davidson NO. Overview and introduction: thematic review series on intestinal. The Journal of Lipid Research 2015;56, 487-488. 
El-Senousey, HK, Fouad, A M. Nutritional factors affecting abdominal fat deposition in poultry: A. Asian-Australasian Journal of Animal Sciences, 2014:27:1057-1068.

Jenkins DJ, Kendall CW, Vuksan V, Vidgen E, Parker T, Faulkner D, et al. Soluble fiber intakeat a dose approved by the US Food and Drug Administration for a claim of health benefits: serumlipid risk factors for cardiovascular disease assessed in a randomized controlled crossover trial. The American Journal of Clinical Nutrition 2002;75:834-839.

Jiang JF, Song XM, Huang $X$, Wu JL, Zhen HC, Jiang YQ. Effects of alfalfa meal on carcass quality and fat metabolism of muscovy ducks. British Poultry Science 2012;53:681-688.

Jin L, Gao YY, Ye H, Wang WC, Lin ZP, Yang HY, et al. Effects of dietary fiberand grit on performance, gastrointestinal tract development, lipometabolism, and grit retention of goslings. Journal of Integrative Agriculture 2014.13:2731-2740

Jing $Y$, Shuang-Shuang Z, Yong-Chang W, Shen-Shen W, Zhi-Peng Y, Lin $Y$, et al. Effects of graded fiber level and caecectomy on metabolizable energy value and amino acid digestibility in geese. Journal of Integrative Agriculture 2016;15:141-147.

Hansen M, Flatt $\mathrm{T}$, Aguilaniu $\mathrm{H}$. Reproduction, fat metabolism, and life span, what is the connection? Cell Metabolism 2013;17:10-19.

Hawthorne SB, Grabanski CB, Martin E, Miller DJ, et al. Comparisons of soxhlet extraction, pressurized liquid extraction, supercritical fluid extraction and subcritical water extraction for environmental solids: recovery, selectivity and effects on sample matrix. Journal of Chromatography A 2000;892:421-433.

He L W, Meng QX, Li DY, Zhang YW, Ren LP. Effect of different fiber sources on performance, carcass characteristics and gastrointestinal tract development of growing Graylag geese. British Poultry Science 2015;56:88-93

He LW, Meng QX, Li DY, Zhang YW, Ren LP. Influence of feeding alternative fiber sources onthe gastrointestinal fermentation, digestive enzyme activities and mucosa morphology of growing Graylag geese. Poultry Science 2015;94:2464-2471.

Hermier D. Lipoprotein metabolism and fattening in poultry. Journal of Nutrition 1997;127:805S-808S.

Hsu JC, Chen LI, Yu B. Effects of levels of crude fiber on growth performances and intestinal carbohydrates of domestic goslings. Asian Australasian Journal of Animal Sciences 2000;13:1450-1454.

Hsu JC, Lu TW, Chiou PWS, Yu B. Effects of different sources of dietary fiber on growthperformance and apparent digestibility in geese. Animal Feed Science and Technology 1996;60:93-102.
Liang K, Vaziri ND. Gene expression of lipoprotein lipase in experimental Nephrosis. Journal of Laboratory and Clinical Medicine 1997;130:387393.

Mateos GG , Jimenez-Moreno E, Serrano MP, Lazaro, RP. Poultry response to high levels of dietary fiber sources varying in physical and chemical characteristics. The Journal of Applied Poultry Research 2012;21:156174.

Matterson L D, Matterson L, Potter L, Stutz N, Singsen E. The metabolizable energy of feedingredients for chickens. Research Rep. Connecticut Agricultural Experiment Station 1965;7:11.

Meng L, Feldman L. A rapid TRlzol-based two-step method for DNA-free RNA extraction from Arabidopsis siliques and dry seeds. Biotechnology Journal 2010;5:183-186.

Pesti GM. Nutrient requirements of poultry. Animal Feed Science and Technology 1995;56:177-178.

Petzinger C, Bauer JE. Dietary considerations for atherosclerosis in common companion avian species. Journal of Exotic Pet Medicine 2013;22(4):358-365.

Roberts CK, Barnard RJ, Liang KH, Vaziri ND. Effect of diet on adipose tissue and skeletalmuscle VLDL receptor and LPL, implications for obesity and hyperlipidemia. Atherosclerosis 2002;161:133-141.

Tabook NM, Kadim IT, Mahgoub O, Al-Marzooqi W. The effect of date fiber supplemented with an exogenous enzyme on the performance and meat quality of broiler chickens. British Poultry Science 2006;47:73-82.

Vicente JG, Isabel B, Cordero G, Lopez-Bote CJ. Fatty acid profile of the sow diet alters fatmetabolism and fatty acid composition in weanling pigs. Animal Feed Science and Technology 2013;181:45-53.

Yang HD, Wang MZ, Song L, Fu ZY. Study of slaughter performance, meat quality and theexpression of $L P L$ gene in Xingyi bantam. Chinese Journal of Animal Science 2009:45:12.

Ye Y, Lin S, Mu H, Tang X, Ou Y, Chen J, et al. Analysis of differentially expressed genes and signaling pathways related to intramuscular fat deposition in skeletal muscle of sex-linked dwarf chickens. Bio Med Research International 2014:7:1-7.

Yost TJ, Jensen DR, Haugen BR, Eckel RH. Effect of dietary macronutrient composition on tissue specific lipoprotein lipase activity and insulin action in normal weight subjects. American Journal Clinical Nutrition 1998;68:296-302

Yu B, Tsai CC, Hsu JC, Chiou PWS. Effect of different sources of dietary fibre on growth performance, intestinal morphology and caecal carbohydrases of domestic geese. British Poultry Science 1998:39:560567 
